\title{
Considerações aCERCa da PRÓlêpSis DE EPICURO
}

\author{
Miguel Spinelli ${ }^{1}$
}

\begin{abstract}
RESUMO: Este artigo se ocupa em averiguar os termos com os quais Cícero, Lucrécio e Diógenes Laércio buscaram tornar compreensível a prólêpsis de Epicuro. Cícero forneceu os termos antecipatio, praenotio e informationem; Lucrécio, notitia, exemplare et vestigia, a fim de dar vOz e expor entre os latinos a doutrina do epicurismo. Diógenes Laércio indicou os termos katalêpsis, dóxa, énnoia, bypólêpsin, com os quais, segundo ele, os próprios epicuristas tentaram explicitar a prólêpsis de Epicuro. Por fim, o artigo expõe a opinião de alguns comentadores contemporâneos.
\end{abstract}

PALAVRAS-CHAVE: Prólêpsis. Antecipatio. Prenotio. notitia. Katalêpsis.

\section{A tradução de Cí́cero e os mal-entedidos Promovidos por ele}

A origem do termo prólêpsis deve-se a um neologismo forjado por Epicuro e por ele introduzido na literatura ou linguagem filosófica. "Coisas novas exigem nomes novos (escreveu Cícero, no De natura deorum), assim como fez Epicuro com o que chamou de prólêpsin, termo que ninguém antes dele fez menção" (CÍCERO, 2000: I, XVII, 45) 2. Cícero contribuiu de duas maneiras quanto ao tema da prólêpsis: uma, positiva, oferecendo os termos latinos (antecipatio e praenotio - antecipação e prenoção) para a linguagem filosófica posterior. O que Epicuro denomina prólêpsin (escreveu Cícero) “[...] é uma antecipação das coisas na mente (anteceptam animo reı) feito uma informação (informationem), condição sem a qual teríamos dificuldade

\footnotetext{
${ }^{1}$ Professor de História da Filosofia Antiga do Departamento de Filosofia da Universidade Federal de Santa Maria, Rio Grande do Sul.

2 "Sunt enim rebus novis nova ponenda nomina, ut Epicurus ipse prólêpsin appellavit, quam antea nemo eo verbo nominarat".
} 
de refletir, de investigar e de discutir o que quer que seja" (CÍCERO, 2000: I, XVI, 44) ${ }^{3}$; outra, negativa, criando (sabendo ou sem saber), com o termo "innatas cognitiones - conhecimentos inatos" (CÍCERO, 2000: I, XVII, 45), um equívoco que se estendeu por boa parte da tradição interpretativa da doutrina de Epicuro.

A tradução de Cícero de prólêpsis para antecipatio e praenotio (antecipação e prenoção) resultou tão acertada que foi acolhida e ainda hoje comparece na maioria absoluta dos comentadores, às vezes, como fossem deles: a prólêpsis, anotou, por exemplo, García Gual (sem qualquer referência a Cícero) "[...] podemos traduzir como preconcepscão ou antecipação" (GUAL, 2008, p. 84). "Quanto ao suposto equívoco promovido por Cícero, pode ter sido apenas resultado de uma má interpretação de suas proposições, visto que ele manifesta plena consciência de que as ideias em Epicuro não são derivadas de outra fonte senão das sensações: da experiência natural humana perceptível. De qualquer modo, Cícero nesse ponto não é claro: ao mencionar que as prólêpsis são inatas, poderia claramente ter acentuado que não são congênitas ou conatas, que, não estando com o indivíduo desde o seu nascimento, então são não natas, e, portanto, foram adquiridas.

Se as prenoções não são nascidas com o sujeito, por certo vieram depois. Elas nascem, segundo Epicuro, em decorrência das humanas percepções naturais que o sujeito tem a respeito das coisas do mundo e que vão se acumulando em sua mente, e, assim, gerando antecipações: forjando noções, conceitos ou ideias opinativas que se estabelecem na mente e que sempre ou cotidianamente interferem nas opiniões (vinculadas a novas percepções) manifestas no presente (no momento atual). A título de ilustração: as prólêpsis de Epicuro expressam um modo de ser ou de portar-se da maioria das pessoas comuns, cotidianas, que perante certa ocorrência, acontecimento ou fato retiram logo de suas lembranças uma opinião pronta e a proferem em tom de certeza e convencimento. Todos nós, com efeito, temos e de quando em quando nos valemos de nossas "velhas opiniões"

Não cabe aqui investigar, apenas conjeturar que a teoria das ideias inatas de Platão pode ter, por contraposto, sugestionado as prólêpsis de Epicuro. Por certo (tema que carece investigar), o conceito de inato não é o mesmo entre ambos,

\footnotetext{
3 "Solus enim vidit primum esse deos, quod in omnium animis eorum notionem inpressisset ipsa natura. [...]. quam appellat prólêpsin Epicurus, id est anteceptam animo rei quandam informationem, sine qua nec intellegi quicquam nec quaeri nec disputari potest".

${ }^{4}$ Nas palavras dele: "[...] la prólepsis, que podemos traducir como preconcepción o antecipación".

${ }^{5}$ Raul Seixas, na Metamorfose Ambulante, cantou as prólêpsis de Epicuro: "Prefiro ser essa metamorfose ambulante que ter aquela velha opinião formada sobre tudo... Quero dizer agora o oposto do que eu disse antes: eu prefiro ser essa metamorfose ambulante que ter aquela velha opinião formada sobre tudo". Na medida em que o cantor se propôs "dizer o oposto", mas disse o mesmo, realçou e reconheceu, que, das velhas opiniões, ninguém está livre.
} 
mas, a rigor, um não repele o outro. Inato, como já visto, não comporta em Epicuro a conotação de congênito, no sentido de algo que tem o seu nascimento contemporâneo ao da mente ou alma humana e que, portanto, corresponderia a algo que nasce com o indivíduo ou que preexiste antes de qualquer referência (do indivíduo atual) ao sensível. Supondo, entretanto, o viés pitagórico da doutrina das ideias platônica, sob esse aspecto, Platão e Epicuro não são tão diversos: formulam a mesma questão por pontos de vista diferentes. No caso dos pitagóricos, dado que a mente ou a alma do indivíduo antecede ao próprio indivíduo (porque as almas são coetâneas e contingentes à alma do mundo), mas se reciclam em cada indivíduo, então as ideias (por não serem todas contemporâneas à eternidade da alma) são, todavia, antecedentes ao indivíduo. As almas acumulam experiências relativas aos indivíduos, e assim vão se intercambiando de indivíduo a indivíduo... São (como mais adiante veremos) as experiências anteriores que constituem as prólêpseis - razão pela qual são antecipações, prenoções; se, nesse sentido, são inatas, assim o são na medida em que se antecipam (antecedem) a qualquer juízo atual decorrente de percepções atuais. O juízo de uma percepção atual conta sempre com a interferência de percepções (experiências) e juízos anteriores, forjados por este ou aquele indivíduo, no percurso do cotidiano da vida - eis aí a questão.

Norman de Witt (talvez influenciado por Cícero) concebe as prólêpseis como ideias inatas (em particular a de Deus e a de justiça) implantadas na mente, e, como tal, segundo ele, bem distintas dos conceitos gerais (epinoiai) obtidos a partir das sensações. De Witt, de modo inconveniente, sobrepôs a Epicuro a anamnese platônica, e assim fez com que as prólêpseis (sob os termos da teoria das ideias inatas de Platão) precedessem a experiência (algo que, em referência a Epicuro, resulta incorreto): “[...] se uma ideia precede qualquer coisa (observou De Witt), isso pode dificilmente ser outra coisa que a experiência. A dita ideia deve ser, por consequência, inata" (DE WITT, 1954, p. 145) 6 . Ora, dado que em Epicuro a ideia não precede a experiência, mas nasce com ela, então a dita ideia não pode ser inata antes de qualquer ou, mais exatamente, de uma primeira experiência (como supõe De Witt); para certas experiências, para aquelas que realizamos pela primeira vez ou para as quais não temos antecedentes (isto cabe em Epicuro admitir) não se impõem antecipações, apenas imaginários ou ideações imaginativas (epibolês). $\mathrm{O}$ anteceder das prólêpseis à experiência requer, antes, alguma experiência, sem a qual não há antecipações, apenas imaginações. É preciso que tenhamos uma primeira experiência (em dependência da qual inevitavelmente forjamos opiniões) e, depois dela, uma outra e uma outra etc., a fim de que possamos (na medida em que tais experiências se conservam na memória) consolidar alguma ideia racionalmente ajuizada.

6 "[...] if an idea precedes or anticipates something, this can hardly be anything but experience. The said idea must therefore be innate". 
Pelo que obervamos, outro equívoco promovido por Cícero (que, aliás, também consta em De Witt) está nos termos tal como ele atribuiu a Epicuro a prólêpsis (por ele dita informationem) que temos a respeito dos deuses. Declara ele que (conforme Epicuro) "[...] a natureza de todos nós admite (omnium natura consentit)" que os deuses existem, e, por esse admitir surte (avalizado por todos) um consenso comum (CÍCERO, 2000: I, XVII, 45). Também aqui o equívoco se deu no conceber essa ideia (suposta como consentida por natureza) como se a todos fosse conatural, no sentido de congênita, inata, nascida com todos, independentemente do perceber sensível sempre predisposto (sobretudo na medida em que a maioria formula sobre o sensível juízos falsos) a promover em nós imaginações e crenças firmes e unânimes. Mas, vejamos como Cícero expôs a questão em termos dados como palavras de Epicuro:

a) "Que a mesma natureza que nos deu a ideia dos deuses, insculpiu em nossa mente a consideração de que são eternos e felizes" (Cícero, 2000: I, XVII, $45)^{7}$. Por esse dizer seria plausível (no contexto da doutrina de Epicuro) apenas admitir (sem aqui fazer algum juízo de valor, se positivo ou negativo) que, assim como a nossa natureza promove em nós a ideia dos deuses, também é de nossa natureza (mais especificamente da natureza de nossa mente) admitir que os deuses são eternos e felizes'; melhor dizendo: não cabe na nossa mente admitir que os deuses são mortais e infelizes - um Deus mortal e infeliz, por suposto, não seria um Deus. "Anaximandro (este relato também é de Cícero, e faz parte do mesmo contexto) é de opinião que os deuses estão sujeitos à geração, pois eles nascem e morrem a longos intervalos... Mas nós (duvida Cícero), como poderíamos conceber um Deus que não seja eterno?" (CÍCERO, 2000: I, X, 25)';

b) Epicuro (escreveu Cícero, de modo mais cauteloso) "[...] afirma que os deuses existem e que a natureza imprimiu em todas as mentes alguma noção a respeito deles" (Cícero, 2000: I, XVI, 44) ${ }^{10}$. Cícero menciona "alguma noção" e não todas. Ora, se a ideia de Deus fosse em nós efetivamente inata, teríamos "toda ideia" a respeito de Deus, e não alguma. Por consequência, também não caberia admitir que a ideia que temos a respeito dos deuses

\footnotetext{
7 "Quae enim nobis natura informationem ipsorum deorum dedit, eadem insculpsit in mentibus, ut eos aeternos et beatos haberemus".

8 "Epicuro diz que Deus é feliz e incorruptível porque é eterno - Epicurus Deum beatum et incorruptum vocat, quia sempiternus est" (LACTÂNCIO, 1990: III, 12).

${ }^{9}$ Anaximandri autem opinio est nativos esse deos longis intervallis... sed nos deum nisi sempiternum intellegere qui possumus?"

10 "Solus enim vidit primum esse deos, quod in omnium animis eorum notionem impressisset ipsa natura".
} 
nos advém "[...] por alguma autoridade, ou por usos e costumes (more), ou por lei", mas apenas por "um consenso admitido por todos (unum omnium firma consensio)" (CÍCERO, 2000: I, XVII, 45) e, obviamente, avalizado por natureza (o que não poderia deixar de ser, na medida em que, para Epicuro, a natureza é o pressuposto certificador de todo e qualquer saber). Se bem que é da "autoridade" de nossa mente, em última instância (e, segundo Epicuro), que retiramos (como já visto, por exemplo), as noções de eternidade e de felicidade dos deuses. Diógenes de Enoanda (o discípulo de Epicuro que mandou insculpir nos muros de sua cidade a doutrina do mestre ${ }^{11}$ ), a esse respeito, dirigiu-se aos seus concidadãos, nestes termos: "Eu nada tornei público a respeito dos deuses que não tivesse apoio no raciocínio <logismós>" (DIÓGENES DE ENOANDA, frag. 30; CHILTON, 1971);

c) Afirma Cícero que Epicuro ensinava que, "[...] em virtude do vigor (modo de ser) e da natureza (vim et naturam) dos deuses, eles não são antes percebidos pelos sentidos, mas pela mente (non sensu, sed mente)". Há aqui uma dificuldade, uma vez que (em dependência dos textos que conhecemos de Epicuro), os deuses não se deixam perceber pelos sentidos nem antes e nem depois de concebidos pela razão! Do que já foi dito, o modo de ser dos deuses (ou seja, a sua eternidade e felicidade, por exemplo), só a mente pode "perceber". Outro dado é que, dos deuses, nada conhecemos (não sabemos algo a respeito deles) ao modo como conhecemos as coisas que Epicuro "[...] denomina de sterémnia", isto é, como coisas sólidas, firmes (soliditate, firmitate - nas palavras de Cícero ${ }^{12}$. Resulta, portanto, que os deuses são apenas seres etéreos... Mas Epicuro não nos ofereceu maiores explicações a esse respeito.

Ajuda-nos de algum modo a compreender a questão o que, por exemplo, Aécio registrou a respeito do como os estoicos conceberam a produção (na mente) de noções ou conceitos (ennoíai) na mente: "A respeito das noções, umas são produzidas sem arte, naturalmente, do modo como já dissemos (isto é, pela sensação, pela memória e pela experiência); outras, a partir de nossos aprendizados e de nossas investigações. Essas são denominadas apenas de noções (ennoíai); aquelas, de antecipações (prólêpseis)..."13. Aécio, pelo que consta, vincula as prólêpseis (sob o ponto de vista estoico) ao que na mente se produz de modo natural ou espontâneo; trata-se (como ele explica) de um produzir que

\footnotetext{
${ }^{11}$ Tratamos demoradamente desse autor no livro Os Caminhos de Epicuro, São Paulo: Loyola, 2006.

12 Termos com os quais Cícero traduziu sterémnia, no De natura deorum (I, XIX, 49). Em Epicuro, na Carta a Heródoto, o termo comparece nos parágrafos 46, 48 e 50, e quer justamente expressar as coisas sólidas.

13 AÉCIO. Placita. IV, 11-12 ; apud LONG, Anthony, A. ;SEDLEY, D.N. (Ed.). The Hellenistic Philosophers. Cambridge: Cambridge University Press, 1987.
} 
se dá mediante um consórcio entre sensação, memória e experiência. Sob esse ponto (o qual explicitaremos mais adiante) epicureus e estoicos aparentemente coincidem $^{14}$, mas não no que concerne à distinção propriamente dita, qual seja, de que a espontaneidade com a qual mente produz as suas noções (as prólèpseis) não expressa com um aprendizado; ao contrário, as noções produzidas na mente por experiência (ou seja, derivadas de sensações repetidas guardadas na memória e que vêm a se constituir em uma experiência - não, a rigor, consolidada, porque as experiências humanas estão sempre abertas, prontas a eventuais mudanças) expressam, para os epicureus, um real aprendizado.

\section{A tradução e a CONCEPÇão de LuCRÉCio}

Lucrécio (distinto de Cícero, e antes de antecipatio e de praenotio) traduziu o termo prólêpsis, no De rerum natura, por notitia, notities ${ }^{15}$. Ele se refere às prólêpseis como se fossem um exemplar, vestígio ou indício (exemplare et vestigia) que nos colocam na senda do conhecimento, ou que, por força de tais indicaçoes, nos levam a nos aventurar em explanações teóricas. São, por vezes, pequenas coisas, frisa ele, que nos fornecem " $[. .$.$] o exemplar das grandes coisas e o vestígio para as notitiai (para$ as notificações, ou informações, ou indicações) que a respeito das coisas podemos ter" (LUCRÉCIO, 1985: II, vv. 123-124) ${ }^{16}$. No trecho em que ele usa noticies, valese também de exemplar e de espécime: "De onde advieram aos deuses o primeiro exemplar (exemplum) para gerar as coisas e também a ideia ou protótipo (noticies) de homens, em vista do que souberam e viram claramente na alma o que fazer?"; e responde: não foi outra coisa "[...] senão a natureza mesma que forneceu aos deuses o espécime (specimen ${ }^{17 *}$ ) da criação" (LUCRÉCIO, 1985: V, vv. 181-185) ${ }^{18}$. Em outro lugar, ele vincula o conceito de noticies com o de prima potestas:

Quanto aos diversos sons, foi a natureza que forçou os homens a emiti-los, e a utilidade a expressar o nome das coisas [...]. Admitir que, primeiro, houve alguém que distribuiu nomes para as coisas, e que, depois, os outros homens aprenderam os primeiros vocábulos, isso é um máximo de loucura. Se um

\footnotetext{
${ }^{14}$ Não dá, com efeito, para prontamente se identificar o que, no geral, estoicos e epicureus conceberam pelo termo prólêpsis.

${ }^{15}$ Cf. notities, IV, v. 479, V, vv. 182 e 1045; notitia: II, v. 745, IV, vv. 476 e 854, V, v. 124 (LUCRÉCIO, 1985).

16 "[...] rerum magnarum parva potest res exemplare dare et vestigia notitiai".

17 * Specimen ou speciem em dependência dos manuscritos Oblongus $(O)$ ou Quadratus $(Q)$. Em qualquer circunstância, diz respeito a um exemplar ou modelo.

18 " [...] exemplum porro gignundis rebus et ipsa notities hominum divis unde insita primum est, quid vellent facere ut scirent animoque viderent [...] si non ipsa dedit specimen natura creandi".
} 
foi capaz [...], como supor que os outros, por essa mesma época, não foram? Ademais, se os outros não fizeram entre si uso das palavras, então de onde para aquele teria advindo noções (notities) de sua utilidade e também o primeiro poder (prima potestas) em vista do que soubera e vira claramente na alma o que fazer? (LUCRÉCIO, 1985: V, vv.1028-1029 e 1041-1049) ${ }^{19}$.

Quer se referindo aos deuses, quer a um suposto alguém que, por primeiro, distribuiu nomes para as coisas, Lucrécio formula, sob duas ilustrações, a mesma pergunta: $1^{\mathrm{a}}$ ) referente aos deuses: de onde retiraram o primeiro exemplar (exemplum) e a ideia (noticies) com "[...] o que viram na alma (animoque viderent) o que fazer?"; $2^{a}$ ) referente a alguém que distribuiu nomes para as coisas, põe a mesma questão: o que o levou a saber e ver na alma o que fazer (facere ut sciret animoque videret)? Por um lado, a questão é a mesma: a fim de que os deuses pudessem "criar", ou, para que alguém pudesse dar nome às coisas, a condição teria de ser esta: estar de posse (na alma) de um exemplar ou modelo, como que de um primeiro poder, mediante o qual saberiam e veriam (na alma) o que fazer. Nesse mesmo contexto: a) relativamente aos deuses, Lucrécio se refere à ideia de homens (notities hominum); b) ao dator de nomes, à ideia de utilidade (notities est utilitatis). Daqui o outro lado da questão, inerente à qual Lucrécio põe em destaque o ver (videre - examinar, observar) e o conhecer (scire - saber, ter a noção).

Se os deuses, como asseverou Lucrécio, detivessem na alma a ideia (notities) de homens, eles careceriam de ter visto homens... Ora, se viram, então, os homens já estavam de antemão dados na empiria (no ver sensível) e, se já estavam, já tinham, evidentemente, sido "criados". Situação semelhante se aplica ao que Lucrécio afirmou quanto ao "ver a utilidade" das palavras na relação com as coisas. Ora, utilidade não é exatamente um algo que se vê, tanto mais que, por utilidade, Lucrécio expressa aqui uma qualidade, serventia, proveito, vantagem. Não sendo, pois, a utilidade algo que se vê (uma imagem que se desloca de um algo concreto), teria, logo, de ser concebida na alma independentemente da empiria. De qualquer modo, o útil (e este é o problema de Lucrécio) não se dá desvinculado de alguma experiência humana relativa a algum uso, costume, usança, ou de alguma prática (práxis) ou exercício de um certo agir. Nesse caso, a ação antecede a compreensão: o fazer (a práxis ou o exercício produtivo) antecede o feito (o resultado). É da ação, por conseguinte, que deriva um determinado modo (útil) de fazer, de tal maneira

\footnotetext{
19 "At varios linguae sonitus natura subegit mittere et utilitas expressit nomina rerum... proinde putare aliquem tum nomina distribuisse rebus et inde homines didicisse vocabula prima, desiperest. nam cur hic posset cuncta notare vocibus et varios sonitus emittere linguae, tempore eodem alii facere id non quisse putentur? Praeterea si non alii quoque vocibus usi inter se fuerant, unde insita notities est utilitatis et unde data est huic prima potestas, quid vellet facere ut sciret animoque videret?”
} 
que a utilidade requer inevitavelmente esse exercício: requer um experienciar que põe à mostra e imprime na mente a ideia do útil.

São, portanto, duas coisas distintas: uma, a noção derivada do sensível; outra, a que se impõe a partir da ação ou do exercício do faz̧er. "Conhecer", em seu sentido mais elementar, significa justamente "ter a noção de". Do ponto de vista de Epicuro/Lucrécio ${ }^{20}$, esse conhecer não se restringe às phantastikè epibolê, às percepções que se lançam sobre ou que se impõem à mente pela via do sensível, e que ficam guardadas no depósito da memória (que se constrói, como ensinou Aristóteles, mediante sucessões de experiências); não se reduz, mas (como consta em Diógenes Laércio, a propósito de Epicuro) é nelas que a "noção de" tem a sua origem. "Todas as nossas epinoiai (escreveu Diógenes, ou seja, tudo o que em nós se projeta na forma de pensamentos) têm a sua origem nas sensações..."; e sobre isso acrescentou: elas nascem (são geradas, têm a sua origem - gegónasi) de vários modos, decorrentes ou do "[...] acaso, ou por analogia, ou por similitude ou por convenção", sendo que para todas essas operações (explica), contamos "com a colaboração do pensar raciocinativo < tou logismou> " (DIÓGENES LAÉRCIO, 2005: X, 32) ${ }^{21}$. Também Sexto Empírico definiu assim o termo prólêpsis vinculado à empiria (com o que acentua a lêpsis, a aquisição, não o que se perdeu, mas o que na mente se conservou ou que por ela foi recepcionado): “[...] é a concepção de algo proveniente da lembrança daquilo que, muitas vezes, esteve presente aos nossos sentidos" (SEXTO EMPÍRICO, 1948: II, n.1). Nesse dizer de Sexto Empírico, vem embutido o que observou Aristóteles na Metafísica: "Da lembrança nasce em nós a experiência; e é de várias recordações da mesma coisa que em nós se produz uma única experiência" (ARISTÓTELES, 1982: I, 1, 980b 28-29).

\section{A tratativa de Diógenes Laércio}

Diógenes Laércio, referindo-se aos epicuristas, sublinha que eles definiam a prólêpsis de quatro maneiras: $\left.1^{2}\right)$ como katalêpsis: termo que expressa uma ação, no sentido de um modo de apreender, de acessar, de possuir, derivado de uma posse ou de uma cognição, em sentido ativo (em atividade), nos termos de uma ingerência, ou seja, de uma posse que interfere constantemente no processo de apreender, de acessar, de possuir, de conhecer; $\left.2^{2}\right)$ como dóxa: qualificada como uma orthê, ou

\footnotetext{
${ }^{20}$ É importante estar atento que a vinculação entre Lucrécio e Epicuro nem sempre é plana, ou seja, se dá numa correspondência linear. Não dá para sustentar, com efeito, que Lucrécio, em certos pontos, reinventa Epicuro; o que faz é buscar, de diversas e outras maneiras, explicá-lo, ou seja, tornar a doutrina de seu mestre compreensiva e finalmente acolhida pelos contemporâneos de Roma.

21 “[...] epinoiai pãsai apò tôn aisthêseôn gegónasi katá te períptôsin, kaì analogian kaì homoiótêta, kaì súnthesin, sumballoménou ti kai tou logismou".
} 
seja, como uma retitude ou ajustamento (entre o objeto percebido e o juízo que a respeito dele formulamos), de modo que a prólêpsis enquanto (ê dóxan orthên) expressaria uma manifestação veraz, na medida em que ajuíza (de modo ajustado) o que é real ou verdadeiro; $3^{\mathrm{a}}$ ) como énnoia (noção, conceito), sem qualquer outro qualificativo. [O que a esse respeito comentou Jean Brun não é de todo afiançável eis o que ele escreveu: que, para a prólêpsis, o sentido de "[...] antecipação ou de prenoção são aceitáveis, o de conceito, utilizado algumas vezes, não o é de maneira alguma; nada é mais estranho à filosofia de Epicuro que essa terminologia racionalista" (BRUN, J., 2003, p. 41) ${ }^{22}$; $4^{\mathrm{a}}$ ) enfim, como ê katolikên nóêsin enapokeiménên, como uma noção, pensamento ou ideia universal guardada ou depositada (na mente), nos termos de uma mnêmê (de uma recordação, uma lembrança) feito um apelo derivado de percepções repetidas de uma mesma coisa ou, inclusive (a tirar pelo que consta nas máximas 37 e 38 de Epicuro), derivado de uma prática ou experiência da vida em comum dos indivíduos (por exemplo, a prática da justiça em decorrência do que é estabelecido por lei). O que o mesmo Jean Brun observou é, nesse caso, bastante elucidativo: "A antecipação (refere-se à prólêpsis) é, pois, um esquema, uma ideia geral; não é uma lembrança (souvenir) disto ou daquilo, mas uma chamada (rappel) de uma pluralidade de experiências semelhantes..." (BRUN, J., 2003, p. 43) ${ }^{23}$.

Se analisarmos com cuidado os quatro modos da prólêpsis descritos por Diógenes Laércio, veremos, em última instância, que eles se restringem a três, se bem que, a par dos quatro significados mencionados, há um quinto, o de conjetura (bypólêpsin). Para entendermos melhor essa questão específica, por certo nos ajuda o que consta na Carta a Meneceu (\ 123-124): "Ímpio (asebês), diz Epicuro, não é aquele que rejeita os deuses do povo, mas o que adere às opiniões (dóxas) que o povo tem a respeito dos deuses. Ora (explica), não são prenoções (prolêpseis), mas falsas conjeturas (bypolêpseis) que o povo sentencia acerca dos deuses". A manifestação de Epicuro é bastante clara: ele diz que a opinião (a dóxa) do povo a respeito dos deuses não é prólêpsis, mas hypolêpsis, ou seja, falsa conjetura. Isso não quer dizer, todavia, que a dóxa, a título de conjetura (bypólêpsin), seja sempre falsa; ao contrário, ela pode ser (tal como a qualifica Diógenes Laércio) "de verdadeira e de falsa” (DIÓGENES LAÉRCIO, 2005: X, 34]. Atribuir, por exemplo, aos deuses poderes para intervir nos fenômenos da natureza (em benefício ou malefício dos mortais) seria enunciar uma bypolêpsis, isto é, forjar uma mera suposição, que, todavia, carece de confirmação. $\mathrm{Na}$ medida em que alguém solicita ao deus

\footnotetext{
22 “[...] anticipation ou prénotion sont acceptables, celle de concept, utilisée quelquefois, ne l'est nullement, rien n'est plus étranger à la philosophie d'Épicure que cette terminoligie racionaliste". Se bem que, na p. 85, Brun reporta-se às prólêpseis, nos termos de noções evidentes.

23 'L'antecipation est donc un schème, une idée générale, elle n'est pas le souvenir de ceci ou de cela, mais le rappel d'une pluralité d'expériences semblables (mnêmên tou mollákis éxôthen phanéntos), comme le précise la définition donnée par Diogène Laërce».
} 
um benefício ou malefício, e que, em consequência, algo eventualmente ocorre, mesmo assim, não há como confirmar (é difícil fazê-lo) se tal ação foi mesmo decorrente do pedido e/ou da ação do deus.

A razão dos quatro significados se restringirem a três se deve ao fato de que o $4^{\circ}$ significado (o da prólêpsis como katholikê nóésis) nada mais é que uma explicitação ou ampliação do $3^{\circ}$, do da prólêpis concebida enquanto énnoia. O curioso dessa ampliação é o teor particularmente aristotélico da linguagem, em termos semelhantes ao que já observamos na definição de Sexto Empírico, quanto à prólêpssis vinculada à empiria. A prólêpsis é, nesse contexto, suposta nos termos de um um comum (viabilizador de conhecimento) derivado, por analogia, de uma pluralidade de experiências em que se sobressaem (por analogia) semelhanças e da qual se retira (por indução) um universal predicativo de conhecimento ou da veracidade, ou seja, de um universal enunciador de algo significante e consistente sobre algo.

Vimos, como Diógenes, referindo-se aos epicureus, ressaltava que eles tratavam "[...] da prolêpsis como se fosse uma katalêpsis (uma apreensão ou possessão $\mathrm{O}^{24}$ )" disponivel em nós feito uma lembrança (mnêmên) de tudo o que, de fora (éxôthen), sorvemos pelos sentidos e que em nós se manifesta de modo claro (phanéntos). O que sorvemos de fora em nós vem a residir, na forma de um depósito guardado na memória, do qual, a qualquer momento, dele podemos nos valer. Por exemplo, se alguém nos diz - isto é um homem, ou isto é um cavalo, isto é um boi -, imediatamente, pela palavra pronunciada (homem, cavalo ou boi), recolhemos na mente a sua forma (týpos) e, com ela, toda uma antecipação preconceitual (toda a prólêpsis) guardada na memória (fruto da mescla entre sensações e opiniões anteriores acumuladas na mente). A significação de cada nome ou, dito de outro modo, todo um conjunto de signos de reconhecimento que o nome evoca à mente, em nós se põe disponível de modo imediato e evidente (enargés). Em vista disso (assim como destaca o próprio Diógenes), eis, relativo às prólêpseis, um princípio canônico de Epicuro: “[...] não podemos buscar o que procuramos sem o conhecer de antemão..."

Cícero disse praticamente o mesmo, que, para Epicuro, sem a posse da prólêpsis (sem uma noção ou conceito prévio) disponível na mente não estamos em condições "[...] de refletir, de investigar e de discutir o que quer que seja" (CÍCERO, 2000: I, XVI, 44) 25. Explicando: não há como nos referirmos, por exemplo, a algo

\footnotetext{
$24 *$ Por vezes, também é traduzida por opinião correta, por pensamento, por ideia geral (por uma katholikê nóêsis, termo que, em geral, define um aspecto ou um dos significados da prólêpsis).

25 "Solus enim vidit primum esse deos, quod in omnium animis eorum notionem inpressisset ipsa natura. [...]. quam appellat prólêpsin Epicurus, id est anteceptam animo rei quandam informationem, sine qua nec intellegi quicquam nec quaeri nec disputari potest".
} 
em termos - isto é, como um homem, como um cavalo, como um toco - sem que, por antecipação, nada saibamos a respeito, ou melhor, como se nunca antes os tivéssemos visto, ou que, frente ao nosso campo de observação, nunca tivesse se apresentado um homem, um cavalo, um toco, e deles não conservássemos o týpos em nossa lembrança. É necessário, pois: a) no caso das coisas empíricas, conhecer por antecipação a imagem (forma) daquilo ao qual nos referimos ou que nos dispomos sobre ele discutir ou investigar; b) no caso de questões não empíricas, carecemos de ter na mente uma prenoção. Se nada em nossa mente conseguimos encontrar relativamente ao que nos propomos discutir e/ou investigar, nem a imagem nem a prenoção, então a investigação e o discurso restam inviáveis.

Neste ponto, observamos em Epicuro algo semelhante ao já tradicionalmente proposto por Heráclito e também por Aristóteles, quanto ao processo do investigar ou do conhecer. Na medida em que expunha o seu logos, Heráclito asseverava fazê-lo do seguinte modo e nos seguintes termos: "[...] detalhando < diaréôn $>$ a natureza de cada coisa e enunciando <phráấn $>$ como é" (DK 22 B 1; DIELS; KRANZ, 1989)26. Esses dois verbos - diairéô (detalhar, distinguir, dividir, definir) e phrázô (indicar, dizer, enunciar, explicar) - vieram a se tornar a expressão tanto da atividade da ciência quanto da habilidade do homem de ciência, do qual são requeridas certas competências. Como pode alguém, por exemplo, fazer ciência, se não sabe distinguir algo de algo, como o botânico que não sabe distinguir uma folha de outra, o médico que não sabe distinguir os órgãos internos de seu paciente etc.? Trata-se, com efeito, de uma capacidade (o distinguir isto daquilo) que se inicia quase que espontaneamente na infância, com a pergunta, sempre muito insistente, o que é isto? - questão que está na base de toda a reflexão filosófica de Parmênides ${ }^{27}$. Por esse perguntar se processa um movimento em que se vincula o perceber (o ver ou visualizar, o sentir) e o enunciar (o nomear algo ou o dotar simbolicamente o que se vê de significação). É, pois, por essa vinculação do perceber sensível com a referência nominativa que se estabelece em nós a capacidade de distinguir algo de algo, uma coisa de outra. Por ela se dá em nós também (e esta, sem dúvida, é a questão de Epicuro) o que ele denomina prólêpsis: por ele concebida como prenoção ou antecipação da mente com que nos tornamos aptos para investigar e discursar (construir falas compreensíveis ou intercomunicativas) a respeito de algo.

\footnotetext{
${ }^{26}$ Eis o conjunto do fragmento: "Este logos, sendo sempre, os homens são incapazes de o compreender, antes ou depois de o haverem ouvido. Pois ainda que tudo aconteça conforme este logos, eles são inexperientes, mesmo experimentando-se em tais palavras e obras, assim como as exponho, detalhando a natureza de cada coisa e enunciando como é <katà phýsin diairéôn hekaston kaì phrázôn hókôs échei>" (SEXTO EMPÍRICO. Contra os Matemáticos, VII, 132, apud DIELS; KRANZ, 1989).
}

27 Sobre a qual tratamos longamente nos Filósofos Pré-Socráticos 2. ed. Porto Alegre: EDIPUCRS, 2003. 
Como falar de bois ou de cavalos, sem antes nunca tê-los vistos? Como falar de justiça, sem ter sequer uma mínima noção a respeito? No que concerne às coisas empíricas, é óbvio que não basta ver. Afinal (e isso Epicuro sabia muito bem), não são os sentidos que nos dão a ciência do que quer que seja. Faz-se necessário, em face do que vemos, formular enunciados significantes. "Conhecer" significa também estabelecer conexões: ligar isto a aquilo ou a pontos de referência mediante critérios. Para que alguém, entretanto, possa fazer isso, quer dizer, estabelecer conexões, é preciso em primeiro lugar saber distinguir, porque quem não sabe distinguir está incapaz de fazer ciência! Também carece de se deter na mente alguma noção, ou melhor, prenoções antecipadas; não, com efeito, noções inventadas, fruto de pura imaginário, de "fantasias" míticas. As antecipações carecem da natural vinculação do (humano) perceber com o nomear, do ver com a necessidade de forjar opiniões... Daí por que as prólêpseis, em vista de todos esses qualificativos (segundo, no caso, a expressão de Diógenes), são de "[...] uma clareza e evidência imediatas” (DIÓGENES LAÉRCIO, 2005: X, 33).

Elas são, ademais, "critérios de verdade"... Ou melhor, dado que verdade e realidade para os gregos são também sinônimos, elas são, isto sim, critérios de certificação da realidade. É pela prólêpsis homem, cavalo, boi, etc. que dou, por antecipação, como previamente conhecido, homens, cavalos, bois... Dessa forma, o que a esse respeito afirma Marcel Conche não parece plenamente acertado. Escreve ele: "As antecipações não são [...] critérios de verdade, e não são evidentes porque ela são imagens genéricas inteiramente fundadas na evidência da sensação" (CONCHE, 1987, p. 25) ${ }^{28}$. Ora, para Aristóteles, homem, cavalo, boi etc. são igualmente "imagens genéricas", mas, mesmo assim, um um comum, na forma de noções ou conceitos gerais com as quais damos por conhecido sujeitos particulares; tais "imagens genéricas" são, inclusive, por ele referidas como a substância (ousía) de sujeitos concretos $^{29}$. Assim, para Aristóteles, como também para Epicuro as noções gerais, que ele denomina de prólêpseis, não são meras imagens genéricas, mas (pelo fato de estarem vinculadas à empiria e ao uso raciocinativo da linguagem) são elas próprias evidências em vista das quais nos pomos em condições de, por exemplo, dizer algo significante a respeito de algo...

É evidente que não dá para argumentar, por exemplo, que a prólêpsis "homem" contenha em si mesma (enquanto noção ou conceito) a mesma ideia geral acessível para todos os indivíduos. Ela contém ou vai de um mínimo a um máximo de representação ou conhecimento - um máximo, aliás, que nunca é pleno,

\footnotetext{
28 "Les anticipations ne sont, comme on verra, critéres de vérité, et ne sont evidentes parce qu'elles sont des images génériques tout entières fondées sur l'évidence de la sentation".

29 Tratamos longamente da questão nos capítulos V e VI do livro Questões Fundamentais da Filosofia Grega. São Paulo: Loyola, 2003.
} 
acabado, visto que a prólêpis concebida por Epicuro participa do movimento dialético do representar e/ou do conhecer. É próprio, digamos, da natureza do conhecer o alargar-se em dependência da disposição, memória ou "depósito" interior à mente humana - não em geral, mas enquanto dada em indivíduos particulares específicos. Vale aqui, a título de ilustração, o que proferiu Heráclito: "Tão longo é o caminho da alma, e tão profundo o logos que ela retém, que jamais encontrarás os seus limites, percorrendo-o" (DK 22 B 45; DIELS; KRANZ, 1989); "Da alma é o lógos que aumenta a si mesmo" (DK 22 B 115; DIELS; KRANZ, 1989) ${ }^{30}$.

A prólêpsis se dá em nós como uma interioridade e em nós experimenta sempre um alargamento em dependência do que está depositado ou preexistente (enapokeiménên - conforme expressão constante em Diógenes Laércio, em sua definição da prólêpsi ${ }^{31}$ ) na mente, e nela está aí sempre à nossa disposição. Esse processo em nós se dá de modo semelhante ao que Epicuro concebeu quanto ao nascimento e alargamento do Kósmos, que, por força de um conglomerado de átomos, é movido, desde a origem, em seu ciclo generativo, e por cujo movimento permanentemente se dá, e se efetiva, a promoção de uma ruptura (tàs ex archês enapólếpsis, conforme consta em Epicuro, na Carta a Heródoto, 77). Entretanto, a enapólêpsis não diz respeito exatamente a um resíduo ou depósito no sentido do verbo enapókeimenai (tal como comparece em Diógenes), mas em dependência desse depósito, a uma ação ao mesmo tempo de ruptura (de interceptação) e de retenção ou aprisionamento de algo. A enapólêpsis referida por Epicuro é (mesmo que complementar) distinta da enapóleipsis que significa justamente depósito, resíduo; donde enapoleípô é o que vai restando ou ficando como depósito.

Há, enfim, em Epicuro toda uma sinfonia de termos relativos à prólêpsis que se complementam e que se explicam reciprocamente. Além da enapólêpsis, temos a katálêpsi ${ }^{32}$, em geral traduzida por apreensão (sensitivo-intelectiva de algo). Referida à prólêpsis, a katálêpis é uma apreensão, não nos termos de uma percepção imediata do sujeito sensiente perante algo que se põe frente ao seu campo de observação; ao contrário, é uma apreensão da opinião continente na memória (resíduo ou depósito cumulativo de saber) solicitada a partir da imagem (da eídôla, como diz Epicuro ${ }^{33}$, em dependência de Platão, ou da phantasía aísthêtikế, como dissera Aristóteles) desenhada na mente em dependência de um certo nome pronunciado - por exemplo, basta a pronúncia da palavra bomem para "vermos" na mente um homem ; boi, para vermos

\footnotetext{
30 Psychês esti lógos heautòn auxôn (ESTOBEU, Florilégio, III, 1, 180a, apud DIELS; KRANZ, 1989).

31 “[...] tên dè prólêpsin... enapokeiménên” (DIÓGENES LAÉRCIO, 2005: XX, 33).

32 “[...] tê dè prólêpsin légousin oionè katalêpsin... Por prolepse, eles (os epicuristas) entendem algo como uma apreensão...” (DIÓGENES LAÉRCIO, 2005: X, 33).

${ }^{33}$ Termo que comparece várias vezes em Epicuro: Carta a Heródoto, 46, 47, 48 e 50; Sentenças Vaticanas, 24.
} 
um boi, e, consequentemente, sabermos a respeito dele algo em decorrência de um acúmulo subjetivo de um saber objetivo, que, como já visto, sempre vai de um mínimo a um máximo de conhecimento. [A Alegoria da Caverna de Platão (logo no início do livro VII da República) é muito instrutiva quanto a esses supostos níveis de verdade ou de conhecimento].

As prólêpsis se constituem em fundamentos semânticos, ou seja, em noções que detêm significados primordiais, de modo que, como já mencionado, elas têm por função expressar a verdade (se se quiser, a realidade) daquilo pelo qual algo é analiticamente referido como sendo de tal forma e que não pode ser de outra maneira, a risco de ser falso (e aqui, aliás, Epicuro resguarda o princípio canônico da ontologia grega segundo o qual o que existe é sempre verdadeiro, real, nunca falso, irreal). O mesmo rigorosamente não se aplica, por exemplo, à justiça, e a noções assemelhadas. A esse respeito, as máximas (37 e 38) de Epicuro podem ainda nos ajudar a compreender melhor o conceito de prôlêpsis, sobretudo enquanto katolikên nóêsin. Eis o raciocício dele (tal como consta na Máxima 33): a justiça só pode ser concebida no contexto das relações recíprocas, não fora dessas relações. O justo se define mediante duas noções, a de comum e a de o mesmo (tò koinòn - tò autô), e pelo proveito em favor dos membros da comunidade (referido na Máxima 36). A função da lei é prescrever a justiça (o que é justo): o comum e o mesmo para todos. É, com efeito, o benefício que a lei traz para as relações recíprocas (na comunidade) que confirma (epimartyroúmenon) a justiça prescrita pela le ${ }^{34}$. Caso não se leve em conta esse proveito (symphéron, synépheren - termos que Lucrécio traduziu por utilitas), a lei (efetivada na vida prática da comunidade) não detém a natureza do justo e, se não detém, resulta em desacordo com a prenoção (prólépsin) da justiça - qual seja, a do proveito (da utilitas) que se manifesta no cotidiano das ações (tà prágmata) da comunidade (ações efetivadas em consonância com a lei ou com o supostamente devido). São, portanto, nos reflexos da lei posta em prática que observamos ou não a utilidade da justiça, e é nessa utilidade (proveito, benefício) que forjamos a prólêpsis, a prenoção do justo, que, por sua vez, pede progressivamente por uma reconsideração e/ou requalificação do supostamente devido.

\section{O REDUCIONISMO DE ALGUNS COMENTADORES}

Boa parte dos comentadores de Epicuro, antes de três ou dos quatro significados da prólêpsis (referidos por Diógenes), registra apenas um: o de katolikên nóêsin, de ideia universal. Léon Robin o enuncia assim: como "[...] uma espécie de pensamento universal que se forma em nós, isto é, uma rememoração do que,

\footnotetext{
${ }^{34}$ Máximas principais, XXXVII e XXXVIII.
} 
de fora, umas quantas vezes se apresentou a nós". E explica: "Se diante de mim alguém diz homem, neve, calor, sei imediatamente do que fala [...]; porém, não o saberia se, antes, não tivesse tido a respeito umas quantas percepções" (ROBIN, 1973, p. $369)^{35}$. Farrington salienta algo semelhante: que as "[...] antecipações podem ser definidas como ideias gerais, como equipamento mental pelo qual organizamos e interpretamos as sensações" (FARRINGTON, 1968, p. 114). Para Cyril Bailey, a "[...] antecipação é um conceito geral, derivado de percepções frequentemente repetidas aos sentidos" (BAILEY, 1964, p. 247) ${ }^{36}$. Jean Balaudé define a prólêpsis como fruto de nossa capacidade de formar ideias gerais, explicitando:

[...] a sensação não deve sobretudo ser concebida como pura receptividade: o que as sensações fazem aparecer é a presença nelas de um movimento de atenção ou de apreensão concomitante ao movimento do pensar. Esse elemento comum ajuda a compreender a passagem da sensação à prenoção; do fato de que todo conhecimento implica uma atividade da parte do sujeito, um ato de atenção, de apreensão, então a prenoção se constitui no seio mesmo da sensação. (BALAUDÉ, 1994, p. 47 e p. 82-83) ${ }^{37}$.

André Laks, na medida em que repete Manuwald (1972, p. 6), entende que a "[...] antecipação é uma memória das percepções anteriores", porém, acrescenta: "Ela se distingue radicalmente da sensação, desprovida de memória" (LAKS, 1976, p. 111-112)

Todos os comentadores aqui focalizados têm um dado em comum: consideram as prólêpsis como um "pensamento universal" ou como "conceito ou ideia geral". Todos também estão de acordo que se trata de rememoraçôes organizadas a partir do sensível ou derivadas do acúmulo de percepções a respeito de uma mesma coisa. Como as prólêpsis são referidas às sensações, todos igualmente vinculam a receptividade do sentir com o movimento do pensar.

\footnotetext{
35 “[...] l'antecipation (prólêpsis), ou prénotion (Lucrèce: notities). C’est une sorte de pensée universelle qui s'est formée en nous, c'est-à-dire une remémoration de ce qui, du dehors, s'est maintes fois présenté à nous. Si devant moi on dit homme, niege, chaleur, je sais immédiatement de quoi on me parle, avant même de le percevoir; mai je ne le saurais pas si, auparavant, je n'en avais en souvent perception".

36 "The antecipation is the general concept, it is derived from frequently repeated sense perceptions".

37 “[...] notre capacié à former des prolepses, des idées générales...”; “[...] la sensation ne doit surtout pas être comprise comme pure réceptivité: ce que ces sensations font apparaittre, c'est la présence en elles d'un mouvement d'attention ou d'appréhension, commun avec la pensée. Cet élément commun aide à comprendre le passage de la sensation à la prénotion: du fait que toute connaissance implique une activité de la part du sujet, acte d'attention, d'appréhension, la prénotion se constitue au sein même de la sensation".

38 "L'antecipation est une mémoire des perceptions antérieures. Elle se dintingue par là radicalement de la sensation, dépourvue de mémoire".
} 
Em vista dessa vinculação (isto os comentadores não dizem explicitamente), poderíamos conceber a prólêpsis sob dois termos (conforme a tradução de Cícero, mas não, a rigor, como sinônimos): a) enquanto prenoção: nesse caso, a prólêpsis (uma vez que vincula o perceber e o pensar) vem a se constituir, da parte do sujeito, mediado por um "ato de atenção", em uma espécie de experiência [quer dizer: a observação repetida de uma quantas vezes da mesma coisa leva o sujeito a um estado de atenção reflexiva e, por ela, liga algo a algo elaborando em sua mente o que Epicuro denominou prenoção (Aristóteles, de experiência, de empeirías)]; b) enquanto antecipação: nesse caso, a prólêpsis, como prenoção, se exerce sobre a atividade sensiente do sujeito, auxiliando-o quer a distinguir algo de algo ou isto daquilo, quer (por força de novas percepções) a reordenar a sua própria mente. Sob esse aspecto, a prólêpsis, enquanto antecipação, e, como tal, enquanto memória de percepções anteriores é uma noção, ideia ou conceito que (depositada na mente do sujeito sensiente) se dá ou se impõe, por antecipação, a qualquer atual e novo exercício do juízo. Portanto, em vista do que aqui está dito, a prólêpsis é, sim (por um lado), "[...] uma memória de percepções anteriores", mas não, restritivamente, como asseguram Manuwald e Laks; por outro (como acrescenta Laks), dá, sim, para dizer que a prólêpsis “[...] se distingue radicalmente da sensação desprovida de memória", todavia, seria preciso explicar que ela coincide com "[...] a sensação provida de memória", ou seja, com aquela sensação que veio a se ordenar, na mente, mediante noções ou conceitos.

De qualquer modo, dizer que a sensação (enquanto sensação) ou que os nossos sentidos não têm memória é bem pouco relevante, sobretudo porque os nossos sentidos (e isso já foi descrito lá entre os ancestrais gregos, pelo pitagórico Alcmeão $\left.{ }^{39}\right)$ não estão desvinculados de nossa atividade cerebral. A rigor, não vemos com os olhos, não ouvimos com as orelhas, mas através dos olhos e das orelhas, e, portanto, vemos e ouvimos com o cérebro. Os nossos órgãos sensientes estão de tal modo vinculados à nossa atividade cerebral que é apenas exercício de abstração querer desvinculá-los. Daí que, percepções, pelo que consta em Epicuro, são atividades mentais, de tal sorte que, para cada pecepção (atual), se impõe um estado presente e, com ele, um modo particular de ver, de ouvir etc. São esses modos que predispõem o que ele denomina prólêpsis.

39 É no cérebro, segundo afirma, que se dão as sensações e, portanto, é por ele, em última instância, que nós vemos, ouvimos, cheiramos e degustamos. É pelo cérebro, salientava, "[...] que nós sentimos os odores...” (AÉCIO, Opiniões, IV, 27 - DK 24 A 8; DIELS; KRANZ, 1989). "A audição depende das orelhas, pois elas contêm o vazio que ressoa [...], e o ar repercute o som... O olfato depende do nariz, órgão que, no respirar, faz penetrar a inspiração até o cérebro. O órgão do gosto é a língua, morna e flexível, onde o calor derrete $<$ os alimentos $>$, e a sua textura, porosa e macia, permite-lhe de receber primeiro e de conduzir. A visão se efetua por meio do líquido que umedece os olhos; que eles contêm fogo é uma evidência... Todas essas sensações são conduzidas ao cérebro segundo um certo processo..." (TEOFRASTO, Sobre os Sentidos, 25-26 - DK 24 A 5; DIELS; KRANZ, 1989). 
A prólêpsis se dá na acumulação e duração do tempo vivido, em que se vai acrescentado (na medida em que se acrescenta) maior saber a uma noção específica ou conceito geral. Nesse caso, sensação e prolepse participam conjuntamente (e, nesse ponto, estamos de acordo com Laks) do "círculo do conhecimento", já que a prólêpsis se modifica constantemente, sob o efeito dos dados atuais fornecidos pelos sentidos, com o que promove um "[...] movimento dialético da representação", inclusive, de alargamento do conceito de prólêpsis para além de uma mera noção ou ideia geral ${ }^{40}$. Trata-se, com efeito, de uma ideia adquirida, porquanto Laks garanta que ela “[...] não é nem uma ideia inata nem adquirida, porque está sempre aí à disposição no funcionamento da linguagem e do pensamento" (LAKS, 1976, p. 111) ${ }^{41}$. Contudo, bem entendido: adquirida não sob o sentido de uma ideia pronta, acabada, e sim sujeita a um permanente fazer-se e, portanto, disponível, quer no interferir, quer no arranjar-se (sob outros cuidados e atenções atuais da mente). Cabe, por fim, às prolepses, visto que se dão de algum modo "consolidadas" na mente, interferir, mais precisamente orientar o afluxo perceptivo e, por suposto, as opiniões que lhe estão vinculadas.

A questão é esta: nem o pensar, nem o sentir em nós se dão, um perante o outro, de modo isolado. Há entre eles o que Epicuro denomina sympátheia, de afetação ou tendência recíproca (termo que os latinos traduziram por consensus). Por sympátheia, ele expressa um compartilhamento, conexão ou liame ${ }^{42}$, mais precisamente, uma tendência ou inclinação natural que reúne os dois, o sentir e o pensar, numa mesma função: promover em nossa mente (alma) a capacidade ou modos de pensar. Isole-se a alma dos sentidos (da corporeidade) e não teremos mais sensações - esse é o princípio da proposição de Epicuro ${ }^{43}$. São as sensações que ligam o pensar com o que está fora de nós, melhor ainda, que levam o de fora para dentro de nós (tôn éxothen prós hêmãs ${ }^{4}$ ). Vale como ilustração o que Sexto Empírico, comentando Heráclito, observou a respeito dos nossos sentidos (por ele dito aisthêtikên pórôn) - que eles são como que as janelas (thyrídôn) pelas quais

\footnotetext{
40 "Ainsi l'action conjointe des sensations et de prolepses embrasse le cercle de la connaissance: la nature de la prolepse se modifie sous l'effet des données qu'apportent les sens, dont l'usage est pourtant rendu possible par la prolepse qui les arrache à l'inanité de l'instant. Ce mouvement dialectique de la représentation est effacé dans l'interpretation qui élargit la notion spécifique de prolepse à celle d'idée générale, puis explique la formation concrète de celle-ci par le dépôt, à l'intérieur de l'esprit..." (LAKS, 1976, p. 112).

41 “La prolepse n'est ni innée ni acquiste, mais toujours déjà, à l'oeuvre dans le fonctionnement du langage et de la pensée".

${ }^{42}$ Carta a Heródoto, 63.

43 "[...] diò apallageísês tês psychês ouk tên aisthêsin - eis porque quando a alma se vai não há mais sensações" (Carta a Heródoto, 64).

${ }^{44}$ Carta a Heródoto, 48.
} 
"[...] entramos em relação com o que nos cerca". Abertas para o mundo, são tais janelas que "[...] ativam em nós a possibilidade do pensamento", a faculdade de pensar (DK 22 A 16; DIELS; KRANZ, 1989); fechadas, aprisionam a alma: desligam-se em nós a luz e a força do pensar. São, pois, pelos nossos sentidos (arraigados à nossa corporeidade) que nos vinculamos ao mundo, ao qual estamos imersos como que por uma raiz.

A íntima relação entre ambos, entre o sentir e o pensar, entre o fora e o dentro de nós, é tão fixa e sólida que estes se carecem reciprocamente. Tal ligação, com efeito, não se dá apenas entre o perceber e o pensar, mas também entre a imagem projetada à mente e o objeto (ou corpo) que a imagem (o fluxo da projeção) reproduz em consonância (no sentido de uma afinidade) com o objeto ${ }^{45}$. Ocorre, conforme observa Epicuro, que, "[...] sem alguma ligação <sympatheias> entre o que se desprende e o que retorna ao objeto não seria possível gerar em nós a percepção <epaísthêsis > "46. A nossa percepção é fruto de uma íntima relação entre sentir e pensar, mas também entre nós e algum objeto do qual sorvemos elementos (átomos, corpúsculos) perceptivos (átomos, por exemplo, promotores do agrado e do desagrado) que nos instruem, tanto o nosso corpo (todo ele concebido por Epicuro como um órgão perceptivo) quanto a nossa mente (que, por sua vez, não se reduz a um órgão estritamente racional). Com efeito, ambos (corpo e alma) em nós não existem isolados: não somos, de um lado, um ser anímico, e, de outro, corporeidade. Somos, isto sim, um todo harmonioso em que o corpo (o sensível) e a alma (o inteligível) se dão unidos e conjugados sem qualquer fissura ou cisão.

Nessa relação corpo e alma, os desejos necessários do corpo (a satisfação de necessidades fundamentais, tais como a fome, a sede) são fáceis de realizar ${ }^{47}$ e, aliás, é próprio da natureza corporal o satisfazer-se com pouco, melhor ainda, é pouco o que "[...] à natureza do corpo" faz falta ${ }^{48}$. Epicuro, com efeito, não observou o mesmo em relação à alma, que, por sua vez, assim como o corpo, deveria se satisfazer com pouco. A alma não se apraz com pouco; não em razão de sua natureza, mas por força das opiniões falsas (da pseudodoxía) e das suposições falsas (das ýpolépseis pseudê̂s) que nela entulhamos e que vêm a ser fonte de grandes males.

"Observem como a maioria dos homens são doentes de falsas opiniões", esculpiu no muro de sua cidade Diógenes de Enoanda (frag. 2; CHILTON, 1971).

\footnotetext{
45 Carta a Heródoto, 50, 52, 65.

${ }^{46}$ Carta a Heródoto, 53.

47 Veja-se Carta a Meneceu, 130-131; Máximas principais, 15, 18; Sentenças vaticanas, 33.

48 "Ergo corpoream ad naturam pauca videmus esse opus omnio - Também para a natureza do corpo observamos ser poucas coisas que lhe falta...” (LUCRÉCIO, 1985: II, vv. 20-21).
} 
Daí a importância edificante da filosofia e sua função libertadora: por um lado, ativar em nós a escuta (a exemplo do que propôs Heráclito ${ }^{49}$ ) da natureza, e não só ouvir a natureza inerente às coisas vivas (nas plantas, nos animais), porém, em nosso corpo e, por esse meio, nos reger; por outro, promover em nós a terapia da alma, quer liberando-a de seus entulhos, quer educando-a a se satisfazer com pouco. Dá-se que as grandiosas e difíceis investigações que impomos à nossa mente, no geral voltadas para questões não evidentes e fundadas em crenças vãs, em nada contribuem para a melhoria de nossa condição humana, sobretudo mais nos adoecem que nos curam. A Natureza nos dotou, sim, de um cérebro (de razão), mas não para com ele nos intranquilizar: para criar para nós mesmos problemas que ultrapassam a nossa capacidade humana de resolvê-los, ou para inventar princípios que não estamos em condições de praticar.

SPINELLI, Miguel. Considerations on the prólêpsis of Epicurus. Trans/Form/Ação, Marília, v. 35, n. 1, p. 3-22, Jan./Abril, 2012.

\begin{abstract}
This article discusses the terms in which Cicero, Lucretius and Diogenes Laertius sought to make sense of the prólêpsis of Epicurus. To give voice to and to divulge among Latin speakers the doctrine of Epicureanism, Cicero furnished the terms antecipatio, praenotio, and informationem, and Lucretius provided notitia, exemplare, and vestiga. Diogenes Laertius presented the terms kataleppsis, dóxa, énnoia, and bypólêpsin, with which, he says, the Epicureans tried to explain the prólêpsis of Epicurus. The article also discusses the views of some contemporary commentators.
\end{abstract}

KEYWORDS: prólêpsis; antecipatio; praenotio; notitia; katalêpsis.

\title{
REFERÊNCIAS
}

ARISTÓTELES. Metafísica. Trad. de Valentín García Yebra. Edição trilingue. Madrid: Gredos, 1982.

BAILEY, Cyril. The Greek Atomists and Epicurus: A Study. New York: Russell \& Russell, 1964.

BALAUDÉ, J. Introduction. In: Lettres, maximes, sentences. Traduction, introduction et commentaires par Jean-Francois Balaude. Paris: Librairie générale francaise, 1994.

BRUN, Jean. L'épicurisme. Paris: PUF, 2003.

\footnotetext{
${ }^{49}$ Assim disse Heráclito: a "[...] sabedoria consiste em dizer a verdade e em agir segundo a natureza, escutando-a" (ESTOBEU, Florilégio, III, 1, 178 - DK 22 B 112, apud DIELS; KRANZ, 1989). O agir humano requer essa escuta, mas carece, todavia, de muito empenho, e por uma razão séria: porque "a natureza ama esconder-se" (Temístios, Discursos, V, p. 69 - DK 22 B 123, apud DIELS; KRANZ, 1989).
} 
CÍCERO. De natura deorum. With an English translation by H. Rackham. Cambridge: Harvard University Press, 2000.

CHILTON, C. W. Diogenes of Oenoanda. The fragments, translation and commentary. Oxford: Oxford University Press, 1971.

CONCHE, M. Introduction. In: . Lettres et Maximes. Texte établie par Marcel Conche. Paris: PUF, 1987.

DE WITT, Norman Wentworth. Epicurus and his philosophy. Minneapolis: University of Minnesota Press; London: Oxford University Press, 1954.

DIELS, Herman; KRANZ, Walther. Die Fragmente der Vorsokeratiker. 18. ed., ZürichHildesheim: Weidmann, 1989.

DIÓGENES LAÉRCIO. Vite e dottrine dei più celebri filosofi. Testo greco a fronte, a cura di Giovanni Reale con la collaborazione di Giuseppe Girgenti e Ilaria Ramelli, Milano: Bompiani, 2005.

EPICURO. Lettres, maximes, sentences. Traduction, introduction et commentaires par JeanFrancois Balaude. Paris: Librairie Générale Francaise, 1994. Lettres et Maximes. Texte établie par Marcel Conche. Paris: PUF, 1987. La lettre d'Épicure [à Hérodote]. Introduction, texte et commentaire avec glossaire, index grammatical et index des mots grecs par Jean Bollack, Mayotte Bollack, \& Heinz Wismann. Paris: Éditions de Minuit, 1971.

FARRINGTON, Benjamin. A Doutrina de Epicuro. Trad. de Edmond Jorge. Rio de Janeiro: Zahar, 1968.

GUAL, Carlos García. Epicuro. Madrid: Alianza Editorial, 2008.

LACTANCIO, Lucio Celio Firmiano. Instituciones divinas. Trad. de E. Sánchez Salor, rev. de P.M. Suárez Martínez. Madrid: Gredos, 1990.

LAKS, André. Édition critique et commentée de la Vie d'Épicure dans Diogéne Laërce X, 1-34. In: BOLLACK, J.; LAKS, A. Cahiers de Philologie. Etudes sur l'épicurisme antique, I. Lille: Press Universitaire, 1976.

LUCRÉCIO. De rerum natura. De la naturaleza. Introducción, traducción y Notas de Eduard Valentí Fiol. Barcelona: Bosch, 1985.

MANUWALD, Anke. Die Prolepsislehre Epicurs. Bonn: Diss, 1972.

ROBIN, Léon. La pensée grecque et les origines de l'esprit scientifique. Paris: Albin Michel, 1973.

SEXTO EMPÍRICO. Contre les moralistes. Traduite par Jean Grenier. In: . Oeuvres Choisies de Sextus Empiricus. Paris: Aubier, 1948.

SPINELLI, M. Os Caminhos de Epicuro. São Paulo: Loyola, 2009.

Recebido em: 10.08.2011

Aprovado em: 08.11.2011 